Raju Tamara Dayu, Adil Mubarak। Peran Pemerintah dalam Pengelolaan Pemakaman pada Masyarakat Etnis Tionghoa di Kota Padang

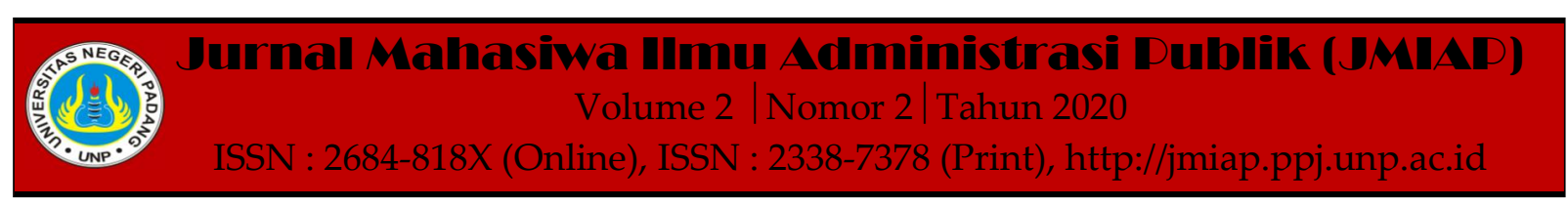

\title{
PERAN PEMERINTAH DALAM PENGELOLAAN PEMAKAMAN PADA MASYARAKAT ETNIS TIONGHOA DI KOTA PADANG
}

\author{
Raju Tamara Dayu' ${ }^{1(a)}$, Adil Mubarak ${ }^{2(b)}$ \\ ${ }^{1}$ Jurusan Ilmu Administrasi Negara, Universitas Negeri Padang \\ ${ }^{2}$ Jurusan Ilmu Administrasi Negara, Universitas Negeri Padang \\ a)raju_tamaradayu@yahoo.co.id, ${ }^{b}$ adilmubarak@fis.unp.ac.id
}

ABSTRACT - This research is motivated by problems regarding the management of cemeteries in ethnic Chinese communities in the city of Padang. The amount of funeral levy fees and cremation problems that are not approved by Minang residents. The research aims to determine: (1) The role of the government in the management of cemeteries in the Chinese community in the city of Padang. (2) Government efforts in overcoming the problems that occur due to the management of Chinese community cemeteries in the city of Padang. (3) Obstacles or obstacles in the management of cemeteries in the Tinghoa community in the city of Padang. This type of qualitative research using descriptive methods ,. The selection of informants is carried out using purposive sampling technique. The type of data is primary data and secondary data obtained from interviews with informants and documents related to research. Data obtained through interviews, observation, and study documentation. The research data were analyzed with source triangulation techniques. The findings in the field show that: (1) The role of the government in funeral management in the Chinese community in the city of Padang, namely as a regulator, is a policy maker in improving or optimizing funeral management. As a dynamicator that is able to get the community to participate in overcoming and efficiency and service improvement. As a facilitator, as a provider of burial grounds and facilitating burial grounds. (2) Obstacles or obstacles in the management of cemeteries in the Chinese community in the city of Padang include the lack of available land. The role of the government is still not maximized in managing Chinese ethics public cemeteries. The lack of socialization to the public about the administration and levies of funeral services and the many forms of graves that are not in accordance with applicable regulations. (3) Government efforts in overcoming the problems that occur as a result of the management of Chinese community cemeteries in the city of Padang, among others, determine policies in the field of funeral services in the form of Regional Regulations. Planning spatial planning, development policy is directed at the realization of a synergistic, harmonious and sustainable city spatial plan supported by realistic and implementative spatial planning documents, strict law enforcement, and the availability of responsible implementing agencies. Expansion of land for the tomb area. Openness of data and information presentation by the Funeral UPTD. Matching the size of the meal with the culture of the people of Padang City who have been accommodated in the Regional Regulation become a standard size.

Keywords : Government Role, Funeral, Management, Chinese Ethnic Community)

Corresponding author. Email.raju_tamaradayu@yahoo.co.id, adilmubarak@fis.unp.ac.id How to cite this article. Dayu, R. tamara \& Mubarak, A. (2020). Peran Pemerintah dalam Pengelolaan Pemakaman pada Masyarakat Etnis Tionghoa di Kota Padang. Jurnal Mahasiwa Ilmu Administrasi Publik (JMIAP) Jurusan Ilmu Administrasi Negara Fakultas Ilmu Sosial Universitas Negeri Padang, Volume 2 (2), Hal. 80-89.

http://jmiap.ppj.unp.ac.id

ISSN : 2684-818X (Online), ISSN : 2338-7378 (Print)

Copyright(C2020. Published by Pusat Kajian-Pemberdayaan dan Pelayanan Masyarakat (PK-P2M) FIS UNP Padang

80 | Jurnal Mahasiwa Ilmu Administrasi Publik | Volume 2 | Nomor 2| Tahun 2020 | (Hal. 80-89) 


\section{PENDAHULUAN}

Dengan berkembangnya pertumbuhan penduduk di wilayah perkotaan mengakibatkan kebutuhan tanah yang sangat meningkat, yang menyebabkan kegiatan pembangunan dan tanah adalah suatu kesatuan yang tidak bisa dipisahkan. Dilihat dari sudut penyediaan infrastruktur yang berada diwilayah perkotaan yang dimana tanah dipergunakan sebagai peran utama dalam kegiatan, maka dari itu dengan meningkatnya harga tanah diwilayah perkotaan menyebabkan dampak besar bagi peningkatan pelayanan sarana ataupun prasarana, termasuk tanah untuk areal pemakaman yang sudah sangat terbatas. Sedangkan peningkatan pelayanan kepada pemerintah adalah tugas utama dan juga salah satu tanggung jawab yang harus dilakukan oleh pemerintah daerah.

Tempat Pemakaman Umum (TPU) adalah salah satu fasilitas umum yang disediakan di setiap kota ataupun wilayah. Tempat pemakaman umum salah satu jenis pemanfaatan lahan yang berfungsi untuk kegiatan yang tidak terbatas dan sangat dibutuhkan namun tidak diinginkan keberadaannya. (Aji, dkk dalam (Kartini, 2018:4).

Berbagai macam jenis tempat pemakaman di indonesia baik yang dikelompokan berdasarkan agama maupun hal lainnya yang menandakan bahwa kebutuhan pemenuhan tanah untuk pemakaman masyarakat indonesia mengalami banyak kendala. Dapat ditemukan dari berbagai pemberitaan media cetak ataupun media elektronik yang dimana banyaknya kendala ataupun permasalahan yang berhubungan dengan tanah pemakaman. Permasalahan mengenai tanah pemakaman sudah termasuk kedalam suau masalah sosial dalam kehidupan bangsa indosenia.

Salah satunya adalah permasalahan yang terjadi di kota Padang. Dengan diberlakukannya perda No 11 tahun 2011 kota Padang tentang retribusi pelayanan pemakaman menimbulkan dampak bagi sekelompok masyarakat etnis Tionghoa, yang dimana perda tersebut memberatkan dalam segi pembiayaan pemakaman. Di dalam perda tersebut ukuran dan biaya yang tercantum bertitik fokus pada standar pemakaman masyarakat muslim, sedangkan di dalam tradisi budaya masyarakat etnis Tionghoa ukuran pemakaman mereka melewati batas standar yang telah ditetapkan dalam perda tersebut.

Ukuran standar untuk makam adalah $2 \times 1$ meter dengan mengeluarkan dana retribusinya mencapai Rp 500 ribu per dua tahun. Sedangkan untuk biaya tanah yang melebihi dari ukuran standar dikenakan retribusi Rp 250 ribu per meter setiap dua tahunnya. Sedangkan ukuran makam masyarakat etnis Tionghoa pada umumnya melebihi dari ukuran standar pemakaman yang telah ditetapkan, yang dimana ukurannya minimal $2 \times 3$ meter untuk satu makam. Dalam budaya Tionghoa makam suami istri biasanya bersebelahan atau berdampingan, maka dibutuhkan biaya yang lebih besar dari biaya pada ukuran makam standar. Menurut beberapa warga masyarakat tionghoa, Perda tersebut sangat memberatkan bagi mereka. Diyakini lamakelamaan kebudayaan etnis tionghoa di kota padang akan pudar. Dikarenakan retribusi pemakaman yang harus mereka keluarkan sangat tidak masuk akal. (sumber berita : Republika, 2015).

Sejak Perda itu diberlakukan banyak dampaknya terhadap masyarakat Tionghoa, diantaranya dari 10 etnis Tionghoa yang meninggal di Padang terpaksa 8 atau 9 di kremasi, sebab takut terbebani dan terancam dibongkar. Dengan berlakunya Perda tersebut masyarakat etnis Tionghoa mengalihkan cara pemakaman mereka dengan melakukan proses krematorium yang dimana proses tersebut mudah dan tidak mengeluarkan biaya yang sangat mahal.

Tetapi berbeda pendapat dengan masyarakat setempat yang ada di daerah tersebut bahwa puluhan warga memprotes lokasi pembakaran mayat (kremasi) yang berada di jalan Pasar Batipuah, kota Padang yang mana dikelola dengan organisasi 
kematian Himpunan Bersatu Teguh (HBT) . masyarakat memprotes karena lokasi itu berada di lokasi padat penduduk dan mayoritas di lingkungan itu muslim yang dapat mengganggu ketentraman mereka dan juga tidak memperhatikan keselarasan lingkungan hidup. (sumber berita : Satu Harapan, 2017).

Kasus dengan penolakkan pembakaran jenazah bagi sekelompok keturunan Tionghoa yang difasilitasi oleh kumpulan sosial kematian Himpunan Bersatu Teguh (HBT) di Pasar Bong (Pecinan) Kelurahan Pondok, Kecamatan Padang Barat Kota Padang merupakan tindakan intoleren, diskriminasi dan sekaligus mencederai budaya ataupun sendi-sendi kebebasan beragama dan berkeyakinan yang dimana itu merupakan hak asasi manusia. Kelompok-kelompok yang menyatakan ormas Islam diwakili GNPF MUI, Forum Masyarakat Minang, Ormas Islam SeSumatera Barat, yang dimana perlakuan mereka terlalu memasuki ruang privat dan keyakinan sekaligus tradisi Komunitas Tionghoa di Kota Padang.

Aksi Penolakan yang dilaksanakan oleh sekelompok ormas intoleran melalui aksi demonstrasi yang dimana melibatkan massa yang mengatasnamakan Islam, mengatakan bahwa pembakaran mayat (krematorium) menganggu masyarakat Islam di sekitarnya. Padahal cara ataupun prosesi pembakaran mayat yang digunakan dengsn melakukan cara modern yaitu menggunakan mesin oven dan mesin pembakaran yang sduah diidentifikasi tidak akan mengganggu kesehatan masyarakat, dan juga kegiatan tersebut dilaksanakan di dalam ruangan tertutup dan tidak dilakukan di setiap harinya. Kepala dinas kebersihan dan pertamanan mengatakan bahwa tiga krematorium yang ada di kota padang tidak satu pun yang memiliki izin, namun pemkot padang perlu juga mempertimbangkan kepentingan dan kebutuhan warga tionghoa. (sumber berita : Harian haluan, 2017). Penelitian ini dilakukan dengan bertujuan untuk mengetahui peran pemerintah, mengetahui hambatan ataupun kendala dan upaya yang dilakukan pemerintah dalam mengatasi permasalahan yang terjadi akibat pengelolaan pemakaman masyarakat Tionghoa di kota Padang

\section{TINJAUAN PUSTAKA}

\section{Konsep Peran Pemerintah}

(Tjokroamidjojo dalam (Heningtyas, Sjamsuddin, \& Hadi, 2014:2)) mengatakan bahwa peran yang dilakukan pemerintah dapat diuraikan dengan berbagai macam bentuk sebagai berikut :

a) Kedudukan pemerintah sebagai pengawas keamanan dan ketertiban dalam perkembangan;

b) Sevice state, yang dimana kedudukan pemerintah merupakan suatu abdi sosial dari keperluan-keperluan yang perlu diatur dalam masyarakat;

c) kedudukan pemerintah sebagai enterpreneur atau pendorong inisiatif usaha dari masyarakat, dimana pemerintah menjadi penggerak dalam pembaharuan pembangunan.

Fungsi pemerintahan terbagi menjadi tiga fungsi yaitu pembangunan, pelayanan, dan pemberdayaan. Dari ketiga fungsi tersebut dikelompokkan lagi terdiri dari dua macam bagian yaitu fungsi primer dan fungsi sekunder. Fungsi primer yaitu fungsi dimana yang berjalan terus menerus dan selalu berkaitan yang bersifat positif dengan kondisi dari piha yang diperintah. Dan mengatur atau mempersiapkan kebutuhan masyarakat terhadap barang dan jas dalam pelayanan publik. Sedangkan fungsi sekunder dimana fungsi yang bersifat berhubungan negatif dengan keadaan politik, ekonomi, dan sosial masyarakat. (Mubarak, 2014).

\section{Konsep Pengelolaan}

(Terry dalam (Tusadikyah, 2017:14)) mengatakan fungsi ataupun kegiatan manajemen pengelolaan terdiri dari perencanaan (planning), pengorganisasian (organizing), pengarahan (actuating), dan pengawasan (controlling).

a) Perencanaan (planning) 
Perencanaan diartikan sebagai alat perhitungan dan suatu penentuan dari apa yang akan dilakukan ataupun dijalankan untuk mencapai tujuan tertentu, dimana berhubungan dengan tempat, bagaimana cara mencapai rencana tersebut, dan oleh siapa pelakunya.

b) Pengorganisasian (organizing)

Pengorganisasian yaitu keseluruhan urutan pelaksanaan yang dimana pengelompokkan orang, tugas, tanggung jawab, alat, dan wewenang sehingga terbentulah suatu organisasi yang bisa dijalankan sebagai wadah dalam mewujudkan tujuan yang telah ditetapkan.

c) Penggerakan (actuating)

Penggerakan merupakan tindakan utnuk menggerakkan orang yang berada di dalam suatu organisasi untuk mencapai tujuan yang telah ditetapkan sebelumnya dengan mengacu pada perencanaan dan pengorganisasian. Penggerakan juga termasuk dalam penetapan dan perumusan kebutuhan dari para pekerja maupun pegawai, memberikan imbalan atau penghargaan, memimpin, mengembangkan dan memberi tunjangan kepada mereka.

d) Pengawasan (controlling)

Pengawasan merupakan proses pengamatan yang dilakukan apakah semua yang telah dilakukan sebelumnya sesuai dengan perencanaan yang telah ditetapkan, dan apakah perintah yang dikeluarkan sesuai dengan prinsip yang telah ditetapkan sebelumnya.

\section{Konsep Pengelolaan Pemakaman}

(Sofian dalam (Kartini, 2018:25)) memiliki beberapa kajian teori tentang pemakaman yang dilihat dari beberapa aspek yaitu :

a) Sosiologi, pemakaman dibutuhkan sebagai bentuk hormat terakhir untuk orang-orang yang telah meninggal dunia serta bentuk kepedulian relasi.

b) Psikologis, pemakaman yang dibutuhkan untuk memberikan kenangan dan juga dukungan moral untuk keluarga yang ditinggalkan. Dukungan moral tersebut dapat berupa melalui simpati dan partisipasi tamu yang datang.

c) Kultural, tradisi budaya upacara pemakaman sudah berjalan dari dahulu hingga sekarang, kembali kepada kepercayaan dan kebutuhan diadakannya upacara pemakaman.

d) Antropologis, dari segi antropologis pemakaman diperlukan dalam hubungan antar manusia karena untuk membuat relasi dan memori tertentu.

\section{Konsep Masyarakat Tionghoa}

Bangsa Tiongkok adalah bangsa yang memiliki sejarah yang panjang dan dikenal dengan salah satu negara yang mempunyai sejarah kebudayaan dan tradisi yang berusia ribuan tahun. Leluhur dari masyarakat etnis Tionghoa di kota padang berasal dari orang asli Tiongkok yang menikah dengan penduduk setempat dan kemudian memutuskan untuk menetap di Indonesia. (Wang dalam (Christian, 2017:1).

Yang menjadi latar belakang budaya, adat istiadat, sejarah, wilayah domisili, karakteristik etnik Tionghoa ini berpengaruh dan terhubung terhadap bagaimana mereka menetapkan posisi dirinya dalam konteks identitas budaya. Politik maupun kekuasaan yang sudah ada di Indonesia juga sangat mempengaruhi identitas budaya etnik Tionghoa di Indonesia. (Hall dalam (Christian, 2017:1)) menuliskan bahwa karakteristik ataupun ciri-ciri dari suatu kebudayaan merupakan suatu penerapan ataupun menghasilkan suatu hal yang tidak pernah ada habisnya, melainkan budaya selalu dalam proses identifikasi dalam konteks sejarah dan budaya.

\section{METODE PENELITIAN}

Jenis penelitian yang akan digunakan adalah jenis penelitian kualitatif yang bersifat deskriptif. Menurut Bogdan dan Taylor dalam (Moleong, 2013:4) penelitian kualitatif ialah penelitian yang menghasilkan data deskriptif berupa kata-kata tertulis ataupun lisan dari pelaku yang diamati. Sedangkan metode deskriptif menurut (Nasir, 2003:53) adalah 
motode yang dimana meneliti sekelompok manusia, satu kondisi, satu objek, suatu sistem pemikiran atau suatu kelas peristiwa pada masa sekarang. Dalam penelitian ini penulis ingin mendeskripsikan bagaimana peran pemerintah dalam pengelolaan pemakaman pada masyarakat Tionghoa di kota Padang. Lokasi penelitian yang akan dilakukan di Kelurahan Pondok kecamatan Padang Barat kota Padang.

Informan ditentukan dengan cara purposive sampling. Sedangkan menurut (Bungin, 2003:53) informan didapatkan dengan cara menentukan informan melalui pertimbangan tertentu yang dapat memberikan data secara maksimal.

Tabel 1. Informan Penelitian

\begin{tabular}{llc}
\hline No & \multicolumn{1}{c}{ Informan } & Jml \\
\hline 1 & $\begin{array}{l}\text { Lurah /Wakil Lurah Kelurahan } \\
\text { Pondok Kecamatan Padang }\end{array}$ & 1 \\
& $\begin{array}{l}\text { Barat kota Padang } \\
2\end{array}$ & $\begin{array}{l}\text { Ketua/Pengurus UPT TPU } \\
\text { Wilayah I Tunggul Hitam Kota }\end{array}$ \\
& $\begin{array}{l}\text { Padang } \\
3\end{array}$ & $\begin{array}{l}\text { Tokoh petinggi etnis Tionghoa } \\
\text { di kota Padang } \\
4\end{array}$ \\
$\begin{array}{l}\text { Masyarakat etnis Tionghoa di } \\
\text { kota Padang }\end{array}$ & 2 \\
\hline
\end{tabular}

Jenis dan sumber data dalam penelitian ini yaitu data primer yang diperoleh dari keterangan-keterangan berdasarkan hasil wawancara yang dilakukan dengan informan yang terkait mengenai peran pemerintah dalam pengelolaan pemakaman pada masyarakat Tionghoa di kota Padang. Data sekunder merupakan data yang bersumber dari studi dokumentasi, buku, makalah, surat kabar, arsip, serta dokumendokumen mengenai peran pemerintah dalam pengelolaan pemakaman pada masyarakat Tionghoa di kota Padang.

Teknik pengumpulan data yang digunakan dengan Obervasi, pengamatan, wawancara dan dokumentasi. . Pengujian tingkat data dilakukan dengan validitas (keabsahan) dan reliabilitas (kepercayaan).
Pengujian validitas bermaksud untuk memastikan bahwa masing-masing pernyataan yang digunakan dalam konsep wawancara adalah tepat dan original serta tidak diambil dari hasil karya orang lain. Sedangkan pengujian reliabilitas bertujuan untuk mengetahui kehandalan dalam pernyataan yang digunakan dalam konsep wawanara untuk terus digunakan pada waktu dan tempat yang berbeda.

Menurut (Moleong, 2013:330-331) adapun teknik yang digunakan dalam menguji keabsahan data ialah triangulasi, yaitu teknik dalam pemeriksaan keabsahan data yang dimana menjadikan sesuatu hal yang lain untuk kepentingan dalam pemeriksaan atau sebagai bahan perbandingan dengan data tersebut

Teknik triangulasi sumber yang dimaksud adalah memadukan ataupun menyamakan serta pengecekan balik tingkatan keperayaan suatu informasi yang diterima melalui orang-orang (sumber) yang berbeda.

Jadi, uji keabsahan data yang akan peneliti lakukan adalah dengan menyatukan data dari hasil wawancara, observasi, dan studi dokumentasi serta mengamati data antara informan yang satu dengan informan yang lainnya terkait dengan peran pemerintah dalam pengelolaan pemakaman pada masyarakat Tionghoa di kota Padang.

\section{HASIL DAN PEMBAHASAN}

Berdasarkan deskripsi data di atas, diperoleh gambaran tentang peran pemerintah dalam pengelolaan pemakaman pada masyarakat etnis Tionghoa di Kota Padang. Pembahasan di bawah ini terbagi atas peran pemerintah dalam perencanaan, pengorganisasian, penggerakkan dan pengawasan dalam pengelolaan pemakaman pada masyarakat etnis Tionghoa di Kota Padang. 
Peran dalam pengelolaan pemakaman pada masyarakat Tionghoa di kota Padang.

\section{a) Perencanaan}

Peran pemerintah dalam perencanaan pengelolaan pemakaman pada masyarakat Tionghoa di kota Padang sudah sesuai dengan Peraturan Pemerintah RI Tahun 1987 yaitu tentang pengaturan tanah untuk memenuhi kebutuhan masyarakat dan sesuai dengan Perda Pemko Padang. Peran pemerintah dalam perencanaan pemindahan lahan kuburan untuk masyarakat Tionghoa yang semula di Gunung Padang dipindahkan ke Bungus Teluk Kabung sesuai dengan rencana pengembangan pembangunan kota Padang yang akan menjadikan Gunung Padang sebagai objek wisata. Disamping itu karena pihak masyarakat Tionghoa tidak memperpanjang kontrak tanah kuburan untuk keluarganya.

Untuk retribusi pemakaman etnis Tionghoa di Bungus Teluk Kabung tidak ada target dalam pemungutan tersebut, target yang diambil hanya dari banyaknya jumlah makam yang diperpanjang. Dalam melakukan pemungutan retribusi UPT TPU Bungus Teluk Kabung tidak mengalami kesulitan karena masyarakat Tionghoa patuh terhadap peraturan yang ditetapkan oleh UPT TPU Bungus Teluk Kabung. Penetapan besaran retribusi juga dilakukan mengingat dengan minimnya tersedia lahan untuk pemakaman, yang terjadi akibat pertambahan penduduk dan kegiatan pembangunan.

Peran pemerintah dalam perencanaan pemungutan retribusi terutama terhadap kelebihan tanah yang digunakan untuk pekuburan masyarakat Tionghoa yang umumnya banyak makan tempat berdasarkan (Peraturan Daerah Kota Padang No 11 Tahun 2011 Tentang Retribusi Jasa Umum Bagian Keempat Retribusi Pelayanan Pemakaman, n.d.), walaupun banyak menuai protes dari warga masyaraka masyarakat Tionghoa, namun sudah sesuai dengan prinsip keadilan bagi seluruh masyarakat Indonesia .
Berdasarkan uraian di atas menunjukkan bahwa perencanaan yang dilakukan Pemda kota Padang dalam pengelolaan pemakaman pada masyarakat Tionghoa di kota Padang sudah dilakukan dengan cara melalui proses pemikiran, melakukan musyawarah dan penentuan secara matang terhadap hal-hal yang akan dilakukan di masa yang akan datang dan menentukan prosedur terbaik untuk mencapainya, dari mulai penyediaan lahan untuk kuburan sampai dengan retribusi.

\section{b) Pengorganisasian}

Peran Pemda kota Padang dalam pengorganisasian pengelolaan pemakaman pada masyarakat Tionghoa di kota Padang sudah sesuai tata kelola pemerintahan daerah yaitu dalam pengelolaan pemakaman masyarakat Tionghoa, Pemda kota Padang menyerahkan pengelolaan pemakaman pada Dinas Lingkungan Hidup Kota Padang. Dinas Lingkungan Hidup Kota Padang mempunyai tugas membantu Walikota Padang dalam melakukan urusan pemerintahan dalam bidang Perumahan dan Kawasan Permukiman, bidang Pekerjaan Umum dan Penataan Ruang sub urusan permukiman yang menjadi kewenangan daerah dan tugas pembantuan yang ditugaskan kepada Daerah.

Peran pemerintah kota Padang sebagai organizing (mengorganisasikan), dalam pengelolaan pemakaman masyarakat Tionghoa yaitu memberi bimbingan terhadap sikap ataupun perilaku yang harus dilakukan kepada Dinas Lingkungan Hidup Kota Padang dan orang-orang yang telibat jika mengalami masalah di TPU. Walaupun begitu Pemda kota Padang tetap mengontrol dan melakukan survey di lapangan untuk mengetahui keadaan yang terjadi.

Berdasarkan hasil peneitian menunjukkan bahwa peran Pemda kota Padang sebagai orgasisator dalam pengelolaan pemakaman masyarakat etnis Tionghoa sudah dilakukan sesuai dengan prosedur yang telah direncanakan. Pembagian kerja yang dilakukan Pemda kota Padang dalam pengelolaan pemakaman 
masyarakat Tionghoa sepenuhnya diserahkan pada Dinas Lingkungan Hidup Kota Padang.

Menurut (Sadyohutomo, 2008:44) bahwa "Pengorganisasian dimaksudkan untuk mengelompokkan kegiatan-kegiatan yang diperlukan dan bagaimana hubungan antar kegiatan tersebut dalam suatu bentuk struktur organisasi atau institusi." Pengorganisasian dalam pengelolaan pemakaman masyarakat Tionghoa di kota Padang terutama terkait dengan retribusi pemakaman yang dilakukan oleh Pemda kota Padang yaitu dengan memadukan seluruh sumber daya yang ada dalam Dinas Lingkungan Hidup Kota Padang.

\section{c) Penggerakkan}

Peran Pemda kota Padang dalam penggerakkan pengelolaan pemakaman pada masyarakat Tionghoa di kota Padang sudah sesuai tata kelola pemerintahan daerah yaitu memberikan arahan kerja kepada bawahan atau kepada Dinas Lingkungan Hidup Kota Padang dalam pengelolaan pemakaman masyarakat Tionghoa. Penggerakkan yang dilakukan Pemda kota Padang yaitu dengan memberikan arahan tugas kepada bawahan di TPU.

Peran Pemda kota Padang sebagai penggerakkan dalam pengelolaan pemakaman masyarakat etnis Tionghoa di TPU Tunggul Hitam, TPU Air Dingin dan TPU Bungus Teluk Kabung diserahkan sepenuhkan kepada Dinas Lingkungan Hidup Kota Padang yang dalam pelaksanaan tugas dilapangan Dinas Lingkungan Hidup menyerahkan sepenuhnya pada UPT TPU. Penggerakkan dalam pengelolaan pemakaman masyarakat etnis Tionghoa ini dimaksudkan agar tercapainya tujuan maupun tujuan sesuai dengan apa yang telah direncanakan sebelumnya. Memberikan petunjuk serta arahan tugas kepada pengawas dan petugas tempat pemakaman di TPU baik TPU Tunggul Hitam, TPU Air Dingin dan TPU Bungus Teluk Kabung kota Padang.
Peran Pemda kota Padang sebagai penggerakkan yaitu memberikan arahan kerja kepada bawahan atau kepada Dinas Lingkungan Hidup Kota Padang selalu pelaksana lapangan baik itu langsung maupun tidak langsung. Pemda kota Padang telah memberikan arahan sesuai dengan perencanaan yang tertuang dalam Perda.

Hal ini sesuai dengan pendapat (Sadyohutomo, 2008:46) bahwa penggerakan (actuating) dalam pengelolaan pemakaman dan retribusi pemakaman tergantung dari gaya memimpin dalam memerintah atau mengarahkan, kemampuan seorang manajer dalam pengambilan keputusan, komunikasi yang dilakukan dalam satu arah dan dua arah, motivasi, dan melakukan koordinasi.

\section{d) Pengawasan}

Peran Pemda kota Padang sebagai pengawasan dalam pengelolaan pemakaman pada masyarakat Tionghoa di kota Padang sudah sesuai tata kelola pemerintahan daerah yaitu melakukan pengawasan atau controlling terhadap rencana yang telah ditetakan sebelumnya melalui Perda apakah sesuai dengan target yang telah ditentukan atau malah sebaliknya.

Pengawasan yang dilakukan oleh Pemda kota Padang melalui Dinas Lingkungan Hidup dalam pengelolaan pemakaman masyarakat Tionghoa sudah berpedoman pada prinsip transparansi, akuntabilitas/ pertatanggung-jawaban, kemandirian dan kewajaran.

Peran Pemda kota Padang dalam pengawasan pengelolaan pemakaman masyarakat etnis Tionghoa sudah efektif. Pengawasan yang dilakukan baik secara langsung dan tidak langsung. Pengawasan langsung yang dimaksud disini adalah pihak atasan mengawasi langsung proses pengelolaan pemakaman masyarakat etnis Tionghoa, Pemda kota Padang melalui Dinas Lingkungan Hidup langsung terjun ke lapangan di TPU. sedangkan pengawasan tidak langsung dimana pihak atasan hanya menerima laporan saja dari pihak bawahan, maksudnya utusan dari pihak Dinas 
Lingkungan Hidup yang bertugas, berkewenangan dan bertanggungjawab dalam mengawasi proses pengelolaan pemakaman masyarakat etnis Tionghoa di TPU Tunggul Hitam, TPU Air Dingin, TPU Bungus Teluk Kabung sebagai pengawas lapangan yang mengawasinya, setelah itu hasil dari pengawasan tersebut dilaporkankan kepada atasan.

\section{Hambatan ataupun kendala dalam pengelolaan pemakaman pada masyarakat Tionghoa di kota Padang}

Berdasarkan deskripsi data hasil penelitian diperoleh gambaran tentang kendala yang dihadapi Pemda kota Padang dalam pengelolaan pemakaman pada masyarakat Tionghoa antara lain :

a) Keterbatasan lahan untuk areal pekuburan masyarakat Tionghoa yang umumnya memerlukan lahan yang luas. Seperti kita ketahui bahwa kuburan masyarakat etnis Tionghoa cenderung menghabiskan tanah lebih luas ukurannya yaitu mencapai 4 x 6 meter atau lebih 22 meter $^{2}$ melebihi ukuran standar makam yang ditentukan yaitu 1 x 2 meter untuk satu kuburan. Hal inilah yang menjadi salah satu kendala dalam pengelolaan tanah pemakaman pada masyarakat Tionghoa di kota Padang.

b) Penerimaan masyarakat Tionghoa terhadap terbitnya Perda No. 11 Tahun 2011 tentang retribusi pemakaman. Perda ini diterbitkan dikarenakan dengan langkanya tanah untuk pemakaman, sebagai akibat dari meningkatnya pertumbuhan penduduk dan kegiatan pembangunan, sehingga Pemda kota Padang perlu melakukan pengaturan tanah untuk memenuhi kebutuhan masyarakat (Peraturan Pemerintah Republik Indonesia Nomor 9 Tahun 1987 Tentang Penyediaan dan Penggunaan Tanah untuk Keperluan Tempat Pemakaman, n.d.). Maka pemerintah Kota Padang membuat Peraturan daerah yang baru yaitu dengan menaikkan retribusi pemakaman, dengan mengeluarkan Peraturan Daerah Kota Padang (2011) No. 11 Tahun 2011 tentang Struktur dan Besarnya Tarif Retribusi kelebihan tanah yang dirasa sangat memberatkan bagi masyarakat Tionghoa. Sebenarnya tarif tersebut berlaku sama, baik untuk kuburan umat muslim maupun non muslim. Namun yang membedakan adalah biaya kelebihan tanah. Oleh sebab itu Retribusi Pemakaman Etnis Tionghoa bisa mencapai lima sampai enam juta rupiah/dua tahun.

c) Mahalnya retribusi pemakaman yang mencapai lima sampai enam juta rupiah/dua tahun membuat masyarakat Tonghoa enggan menguburkan Jenazahnya. Tentu saja hal ini juga berdampak pada jasa penggalian kubur dan pembangunan makam yang biasanya menjadi penghasilan tambahan bagi masayarakat sekitar pekuburan ikut berkurang. Rendahnya jumlah jenazah yang dimakamkan terjadi setelah Perda Retribusi Pemakaman disahkan. Mahalnya biaya kelebihan tanah yang mencapai lima sampai enam juta per dua tahun menjadi keluhan etnis Tionghoa ini, sehingga membuat masyarakat Tonghoa enggan menguburkan Jenazahnya keluarganya dan lebih memilih membakar jenazah kerabatnya. Kalau yang membakar rata-rata seminggu ada satu orang, artinya sejak awal tahun 2015 hingga November 2015 sudah ada sekitar 50-an kali pembakaran. Disayangkan pembakaran jenazah ini tidak ada retribusinya, dan hal ini juga berdampak untuk pemerintah karena berkurangnya PAD dari retribusi pemakam Tionghoa. 
Upaya Pemerintah dalam mengatasi Permasalahan yang terjadi akibat pengelolaan pemakaman masyarakat Tionghoa di kota Padang

Upaya pemerintah dalam mengatasi permasalahan yang terjadi akibat pengelolaan pemakaman masyarakat Tionghoa di kota Padang antara lain :

a) Upaya yang dilakukan pihak pemda kota Padang terkait dengan permasalahan yang muncul dalam pengelolaan pemakaman masyarakat Tionghoa yang diakibatkan oleh Perda No. 11 tahun 2011 yiatu merevisi kembali peraturan tersebut, sehingga pada tanggal 1 Agustus 2016 terjadi perubahan beberapa pasal pada Perda No. 11 tahun 2011 salah satunya yaitu Pasal 26 yang membahas tentang biaya pengabuan dan pemakaman, peraturan ini berisi tentang biaya pemakaman Tionghoa menjadi kurang lebih dua juta perdua tahun.

b) Upaya yang dilakukan oleh masyarakat etnis Tionghoa agar biaya retribusi pemakaman di Bungus Teluk Kabung diturunkan yaitu mengajukan usulan melalui DPRD Padang, sehingga pada pada tanggal 29 Desember 2015 ada dua Ranperda yang berhasil disahkan, yakni Ranperda Kota Padang tentang perubahan kedua atau peraturan Daerah Kota Padang No. 11 Tahun 2011 tentang Retribusi Jasa Umum, dan Ranperda Kota Padang tentang Perubahan Atas Peraturan Daerah Kota Padang No. 12 Tahun 2011 tentang Retribusi Jasa Usaha. Walaupun retribusi sudah diturunkan tetapi tidak banyak masyarakat Tionghoa yang mau memakamkan jenazah kerabat mereka di TPU Bungus Teluk Kabung. Banyak di antara mereka lebih memilih jenazah kerabat mereka dikremasi dari pada dimakamkan. Akibatnya muncul perubahan tradisi dari etnis Tionghoa, di mana mereka yang semulanya cenderung memakamkan keluarga mereka sehingga memilih untuk kremasi, karena kremasi ini dianggap meringankan biaya.

Menurut (Pamudji dalam (Syahputra, 2017)) pengelolaan disisni berfokus pada dua faktor yaitu : (1) Pengelolaan merupakan upaya pengembangan serta pembentukan yang dapat memindai suatu hal sehingga menjadi yang baru dan memiliki nilai yang lebih tinggi, (2) Pengelolaan sebagai upaya pembaharuan yaitu usaha memelihara sesuatu agar lebih cocok dengan kebutuhan.

\section{PENUTUP}

Setelah dilakukan penelitian tengan peran pemerintah dalam pengelolaan pemakaman pada masyarakat etnis Tionghoa di kota Padang maka dapat disimpulkan :

1) Peran pemerintah dalam pengelolaan pemakaman pada masyarakat Tionghoa di kota Padang yaitu sebagai regulator ialah penentu kebijakan dalam meningkatkan atau mengoptimalkan pengelolaan pemakaman. Sebagai dinamisator yaitu mampu mengupayakan masyarakat ikut serta dalam mengatasi dan efisiensi dan peningkatan layanan. Sebagai fasilitator yaitu sebagai penyedia lahan pemakaman dan memfasilitasi lahan pemakaman.

2) Hambatan ataupun kendala dalam pengelolaan pemakaman pada masyarakat Tionghoa di kota Padang antara lain kurangnya ketersediaan lahan yang ada, Masih belum maksimalnya peran pemerintah sebagai regulator dalam mengelolah pemakaman umum etinis Tionghoa, serta Kurangnya sosialisasi yang dilakukan pemerintah kepada masyarakat.

3) Upaya pemerintah dalam mengatasi permasalahan yang terjadi akibat pengelolaan pemakaman masyarakat Tionghoa di kota Padang antara lain 
menetapkan kebijakan di bidang pelayanan pemakaman dalam berbentuk Perda. Merencanakan penataan ruang, kebijakan pembangunan diarahkan pada perwujudan tata ruang kota yang sinergis, Perluasan lahan untuk area makam. Keterbukaan penyajian data dan informasi oleh pihak UPTD Pemakaman. Menyeseuaikan ukuran makam dengan identitas budaya masyarakat Kota Padang yang telah ditindakan dalam Perda menjadi ukuran standar.

\section{DAFTAR KEPUSTAKAAN}

Bungin, B. (2003). Analisa Data Penelitian Kualitatif: "Pemahaman Filosofis dan Metodologis ke Arah Penguasaan Model Aplikasi. Jakarta: Raja Grafindo.

Christian, S. A. (2017). Identitas Budaya Orang Tionghoa Indonesia. Jurnal Cakrawala Mandarin, $\quad 1(1), \quad 11$. https://doi.org/10.36279/apsmi.v1i1.11

Harian haluan. (2017). Sejumlah Kelompok Masyarakat Tolak Krematorium di Pecinaan Padang. Retrieved from https://www.harianhaluan.com/news/detai 1/64306/sejumlah-kelompok-masyarakattolak-krematorium-di-pecinan-padang

Heningtyas, M. A., Sjamsuddin, S., \& Hadi, M. (2014). Peran Pemerintah Dan Masyarakat Dalam Upaya Pengembangan Pendidikan Nonformal (Studi Kasus: Eksistensi "Kampung Inggris" Kabupaten Kediri). Jurnal Administrasi Publik Mahasiswa Universitas Brawijaya, 2(2), 264-268.

Kartini. (2018). Analisis Ambang Batas Lahan Pemakaman di Kota Makassar. UIN Alauddin Makassar. https://doi.org/10.31764/jpe.v4i2.1025

Moleong, L. J. (2013). Metode Penelitian Kualitatif. Bandung: PT. Remaja Rosdakarya.
Mubarak, A. (2014). Peran Ormas dalam Menjalankan Fungsi Pemerintah Bidang Pemberdayaan. Jurnal Seminar Nasional UT.

Nasir, M. (2003). Metode penelitian. Jakarta: Ghalia Indonesia.

Peraturan Daerah Kota Padang No 11 Tahun 2011 Tentang Retribusi Jasa Umum Bagian Keempat Retribusi Pelayanan Pemakaman.

Republika. (2015). Perda Kota Padang Dinilai Ancam Budaya Masyarakat Tionghoa. Retrieved from https://www.republika.co.id/berita/nasion al/daerah/15/05/27/np0djq-perda-kotapadang-dinilai-ancam-budayamasyarakat-tionghoa

Sadyohutomo, M. (2008). Manajemen Kota dan Wilayah: Realita \& Tantangan. Jakarta: Bumi Aksara.

Satu Harapan. (2017). Menag Minta Tuntutan Penutupan Krematorium Diselesaikan Melalui Dialog. Retrieved from http://www.satuharapan.com/readdetail/read/menag-minta-tuntutanpenutupan-krematorium-diselesaikanmelalui-dialog

Syahputra, U. D. (2017). Analisis Pengelolaan Pemakaman Untuk Meningkatkan Pelayanan Publik di Pemakaman Umum Gajah Mada Kota Medan. Universitas Medan Utara.

Tusadikyah, N. (2017). Pengelolaan Perpustakaan Dalam Upaya Peningkatan Minat Baca Siswa Di Sekolah Dasar Negeri Kauman 1 Malang. Tesis Universitas Islam Negeri Maulana Malik Ibrahim Malang. https://doi.org/10.16309/j.cnki.issn.10071776.2003.03.004 